\title{
ABSENCE OF CHOLESTEROL SYNTHESIS AS CONTRASTED WITH THE PRESENCE OF FATTY ACID SYNTHESIS IN SOME ARTHROPODS
}

\author{
D. I. ZANDEE \\ Laboratory of Chemical Animal Physiology, University of Utrecht, The Netherlands
}

(Received 4 October 1966)

\begin{abstract}
After administration of acetate-1-14C absence of cholesterol synthesis was demonstrated in the lobster Homarus gammarus (L.), the spider Avicularia avicularia (L.) and in the millepede Graphidostreptus tumuliporus (Karsch).

2. However, the animals utilize acetate for the synthesis of fatty acids (except for polyunsaturated ones) and for some non-saponifiable lipids.

3. Gas-liquid chromatography analyses demonstrated even- and oddnumbered fatty acids, saturated and unsaturated ones, iso, anteiso and probably neo-branched-chain fatty acids.

4. The fatty-acid composition of the mixtures from the animals and the biosynthesis of the fatty acids are discussed.
\end{abstract}

\section{INTRODUCTION}

IT is recognized that insects generally require a dietary sterol for optimum growth and development (Gilmour, 1961; Clayton, 1964). Many species of insects, mostly phytophagous and omnivorous ones, can modify the sterols from their diet (Bergmann, 1962).

Isotopic tracer techniques have been used to demonstrate the absence of cholesterol synthesis in insects (Bloch et al., 1956; Clark \& Bloch, 1959; Kodicek \& Levinson, 1960; Robbins et al., 1960; Sedee, 1961; Kaplanis et al., 1961, 1963).

It is interesting that the insects are not the only arthropodean class in which the biosynthesis of sterols is absent or defective. Crustacea too fail to utilize acetate to synthesize cholesterol. This was found for the crayfish Astacus astacus (L.) (Zandee, 1962), studied for several seasons, after administration of sodium acetate-1-14 C (Zandee, 1964, 1966a) and after administration of mevalonic acid${ }^{2-14} \mathrm{C}$ (Gosselin, 1965). The crab Cancer pagurus (L.) lacks the ability to synthesize cholesterol from acetate-1 $1{ }^{14} \mathrm{C}$ or mevalonic acid-2-14 $\mathrm{C}$ too (Van den Oord, 1964a).

The present study reports the absence of cholesterol biosynthesis in another crustacean species, namely Homarus gammarus (L.). One representative of the class Arachnida, Avicularia avicularia (L.), and one of the Myriapoda, Graphidostreptus tumuliporus (Karsch), have been studied in this order. Information on these Arthropoda classes would be of great interest since the results obtained with insects and crustaceans do suggest that the phenomenon will range over the whole phylum Arthropoda. 
To investigate the phenomenon mentioned in these animals sodium acetate${ }^{1-{ }^{14} \mathrm{C}}$ was used. Many investigators prefer an immediate precursor like mevalonic acid or squalene for the study of the biosynthesis of sterols in animals (Fagerlund \& Idler, 1960; Wootton \& Wright, 1962). When mevalonic acid or squalene is not incorporated into the cholesterol the results are evidence for the absence of sterol synthesis. However, there is no evidence at all of metabolic activity for other compounds like fatty acids or amino acids. It is possible that in animals like mussels, which are injected at random (Fagerlund \& Idler, 1960), the dose will be lost in the surrounding water. Moreover, it may occur that metabolically the animals are barely active so that hardly any incorporation of ${ }^{14} \mathrm{C}$ of the acetate into the isolated substances will be found. It is also conceivable that the animals investigated did not synthesize sterols during the experiments, since a sufficient amount of that material was already present. This will especially apply to metabolites with a small turnover rate.

In this paper the fatty-acid composition of the animals investigated is described and the biosynthesis of the fatty acids is also discussed.

\section{MATERIALS AND METHODS}

The lobster, Homarus gammarus, was caught in the North Sea near the coast of Holland in summer. The animal was kept in running sea water at a temperature of $16^{\circ} \mathrm{C}$.

Three spiders, Avicularia avicularia, were obtained from Equador via a banana importer. They were kept at a temperature of $25^{\circ} \mathrm{C}$ and fed with Tenebrio larvae.

Ten millepedes, Graphidostreptus tumuliporus, were collected from the vicinity of the Institut Français d'Afrique Noir, Dakar, Senegal. In the laboratory they were placed in glass troughs, containing moist soil, at a temperature of $26^{\circ} \mathrm{C}$. They were fed with vegetables and fruit and were provided with water.

The lobster, fresh weight $1663 \mathrm{~g}$, was injected four times at intervals of $24 \mathrm{hr}$. Each injection consisted of $100 \mu \mathrm{c}$ of sodium acetate-1-14 $\mathrm{C}$ (specific activity, $10 \mu \mathrm{c} / \mathrm{mg}$ ) in $1 \mathrm{ml}$ of water. The three spiders (total fresh weight $20.6 \mathrm{~g}$ ) were injected with the same acetate solution. They received one injection of about $1 \mu \mathrm{c} / \mathrm{g}$ animal. In the same way ten millepedes (total fresh weight $102 \mathrm{~g}$ ) were injected with about $1 \mu \mathrm{c} / \mathrm{g}$ animal. After a period of 4 days the lobster was killed and divided into three portions, namely hepatopancreas, muscles and remaining parts. Each portion was saponified in $1.5 \mathrm{~N}$ potassium hydroxide in $80 \%$ methanol. The spiders and millepedes were killed $24 \mathrm{hr}$ after injection and saponified whole in $1.5 \mathrm{~N}$ potassium hydroxide in $80 \%$ methanol. The saponifications were carried out under reflux for about $5 \mathrm{hr}$ in an atmosphere of nitrogen. The saponification mixtures were then filtered and the non-saponifiable and the saponifiable lipids were extracted with light petroleum ether in the usual manner. The extracts were pooled and dried over anhydrous sodium sulphate. In addition the saponifiable lipid fraction (fatty acids) was treated with activated charcoal (B.D.H.). Further preparation of the non-saponifiable material to be used for isotope determinations was carried out by chromatography on columns of aluminium oxide as previously 
described (Zandee, 1966a). Activities from the various fractions were determined on $\mathrm{BaCO}_{3}$ samples of infinite thickness* or on infinitely thin layers $\dagger$ on aluminium planchets with a Philips Geiger-Müller counter.

The isolated fatty acids from the saponifiable lipid fraction were stored in petroleum ether at $-20^{\circ} \mathrm{C}$. The methyl esters of the fatty acids obtained by the method of Schlenk \& Gellerman (1960) were analysed by gas-liquid chromatography. The analyses were made with a Becker instrument equipped with katharometer detection. Columns were filled with 20 per cent by weight of ethylene glycol adipate polyester and 2 per cent of phosphoric acid on 60-80 mesh Chromosorb-W. The column temperature was approximately $182^{\circ} \mathrm{C}$. Further details and identification procedures have been described in an earlier report (Zandee, 1966b). Peaks of the original and the hydrogenated samples were collected on anthracene cartridges (according to Karmen et al., 1962) and the radioactivity of the fatty acids was determined with an I.D.L. liquid scintillation counter, type 2022. The activities were expressed in counts min $^{-1} \mathrm{mg}^{-1}$ methylated fatty acid (specific activity) at 100 per cent efficiency.

\section{RESULTS}

The quantities of the isolated lipid fractions are summarized in Table 1. The high content of unsaponifiable material, especially sterols, and also fatty acids in the hepatopancreas of Homarus as compared with the muscles and remaining parts, is in conformity with the known results for Cancer pagurus (Renaud, 1949; Vonk, 1960). It is remarkable that in all animals the quantity of the crude squalene fractions was greatly polluted with hydrocarbons and perhaps wax-like substances.

TABle 1-Quantities OF ISOLATED LIPID FRactions

\begin{tabular}{|c|c|c|c|c|c|c|}
\hline & \multicolumn{4}{|c|}{ Homarus } & \multirow[b]{2}{*}{ Avicularia } & \multirow[b]{2}{*}{$\begin{array}{l}\text { Graphido- } \\
\text { streptus }\end{array}$} \\
\hline & $\begin{array}{l}\text { Hepato- } \\
\text { pancreas }\end{array}$ & Muscles & $\begin{array}{c}\text { Remaining } \\
\text { parts }\end{array}$ & Total & & \\
\hline $\begin{array}{l}\text { Total fresh } \\
\text { wt. (mg) } \\
\text { Unsaponifiable }\end{array}$ & 70,000 & 369,000 & $1,220,000$ & $1,659,000$ & 20,600 & 102,000 \\
\hline $\begin{array}{l}\text { lipids (mg) } \\
\text { (Fresh wt., \%) } \\
\text { Crude squalene }\end{array}$ & $\begin{array}{l}668 \\
0.95\end{array}$ & $\begin{array}{l}173 \\
0.05\end{array}$ & $\begin{array}{l}260 \\
0.02\end{array}$ & $\begin{array}{r}1101 \\
0.07\end{array}$ & $\begin{array}{l}83 \\
0 \cdot 40\end{array}$ & $\begin{array}{l}108 \\
0 \cdot 11\end{array}$ \\
\hline $\begin{array}{l}\text { (mg) } \\
\text { Crude sterols }\end{array}$ & 43 & - & 13 & 56 & 7 & 6 \\
\hline $\begin{array}{l}\quad(\mathrm{mg}) \\
\text { (Fresh wt., \%) } \\
\text { Fatty acids }\end{array}$ & $\begin{array}{l}380 \\
0.543\end{array}$ & $\begin{array}{l}138 \\
0 \cdot 037\end{array}$ & $\begin{array}{r}141 \\
0.011\end{array}$ & $\begin{array}{l}659 \\
0.04\end{array}$ & $\begin{array}{l}48 \\
0.233\end{array}$ & $\begin{array}{l}86 \\
0 \cdot 084\end{array}$ \\
\hline $\begin{array}{l}(\mathrm{mg}) \\
\text { (Fresh wt., \%) }\end{array}$ & $\begin{array}{r}2740 \\
3.91\end{array}$ & $\begin{array}{l}78 \\
0.02\end{array}$ & $\begin{array}{r}6430 \\
0.53\end{array}$ & $\begin{array}{l}9248 \\
0.56\end{array}$ & $\begin{array}{l}170 \\
0 \cdot 83\end{array}$ & $\begin{array}{l}101 \\
0 \cdot 10\end{array}$ \\
\hline
\end{tabular}

* According to Calvin et al., 1949.

$\dagger$ Counts were corrected to zero mass. 
The radioactivity of the crude squalene fractions appeared to belong to the hydrocarbons only. The squalene hexahydrochlorides formed by the Heilbron method and modified by Loud \& Bucher (1958) nowhere showed radioactivity. In the carnivorous spiders a higher percentage of sterols and fatty acids was found than in the herbivorous millepedes.

The results of the radioactivities of the isolated lipid fractions are shown in Table 2. Neither cholesterol nor squalene contains radioactivity, so it must be concluded that these representatives of the phylum Arthropoda cannot synthesize cholesterol or other sterols from acetate either. In all cases, however, the animals utilized acetate for the synthesis of fatty acids and some non-saponifiable lipids. The activity of the wax-like substances and hydrocarbons from both Avicularia and Graphidostreptus was notably high.

TABLE 2-RADIOACTIVITY* OF THE ISOLATED LIPID FRACTIONS EXPRESSED IN COUNTS/MIN AFTER ADMINISTRATION OF ACETATE- $1-{ }^{14} \mathrm{C}$

\begin{tabular}{|c|c|c|c|c|c|}
\hline & \multicolumn{3}{|c|}{ Homarus } & \multirow[b]{2}{*}{ Avicularia } & \multirow[b]{2}{*}{$\begin{array}{l}\text { Graphido- } \\
\text { streptus }\end{array}$} \\
\hline & $\begin{array}{l}\text { Hepato- } \\
\text { pancreas }\end{array}$ & Muscles & $\begin{array}{l}\text { Remaining } \\
\text { parts }\end{array}$ & & \\
\hline $\begin{array}{l}\text { Unsaponifiable } \\
\text { fraction }\end{array}$ & $10 \cdot 8 \pm 0 \cdot 6$ & - & $89 \cdot 1 \pm 1 \cdot 1$ & $85 \cdot 3 \pm 1 \cdot 0$ & $1712 \cdot 1 \pm 4 \cdot 1$ \\
\hline $\begin{array}{l}\text { Wax-like substances } \\
\text { from the unsaponi- } \\
\text { fiable fraction }\end{array}$ & $11 \cdot 2 \pm 0 \cdot 4$ & 一 & - & $552 \cdot 5 \pm 2 \cdot 3$ & $10,975 \cdot 0 \pm 11 \cdot 0$ \\
\hline $\begin{array}{l}\text { Squalene hexahydro- } \\
\text { chloride }\end{array}$ & $0.5 \pm 0.4 \dagger$ & - & $0.3 \pm 0.4 \dagger$ & $0.4 \pm 0.5 \dagger$ & $0.9 \pm 0.6 \dagger$ \\
\hline Cholesterol digitonide & $0.5 \pm 0.8$ & $0.3 \pm 0.5$ & $0.6 \pm 0.5$ & $0.9 \pm 0.6$ & $0 \cdot 2 \pm 0 \cdot 5$ \\
\hline Cholesterol & $0.06 \pm 0.4$ & $0.1 \pm 0.5 \dagger$ & $0.1 \pm 0.5$ & $-0.2 \pm 0.5$ & $1 \cdot 0 \pm 0 \cdot 6$ \\
\hline Fatty acids & $13 \cdot 1 \pm 0 \cdot 6$ & $29 \cdot 4 \pm 0 \cdot 5$ & $170 \cdot 5 \pm 1 \cdot 4$ & $91 \cdot 1 \pm 1 \cdot 1$ & $1292 \cdot 1 \pm 3 \cdot 6$ \\
\hline $\begin{array}{l}\text { Melting point of } \\
\text { cholesterol }\left({ }^{\circ} \mathrm{C}\right)\end{array}$ & $146 \cdot 7$ & - & $147 \cdot 6$ & $148 \cdot 0$ & $146 \cdot 3$ \\
\hline
\end{tabular}

* In counts/min per infinitely thick $\mathrm{BaCO}_{3}$ sample measured with the G.-M. tube.

$\dagger$ Infinitely thin layers on aluminium planchets.

The identities and the percentage composition of the fatty acids are summarized in Table 3. The values presented in this table are the mean values of at least five chromatograms with at least two runs of hydrogenated mixtures. The fatty-acid analyses show large amounts of palmitic $(16: 0)$ and oleic $(18: 1)$ acid in all cases. There are important differences between the fatty-acid composition of the hepatopancreas, muscles and remaining parts of Homarus. The hepatopancreas showed the greater variety in fatty acids. Straight and branched-chain saturated acids with an even and odd number of carbon atoms were present. Mono-unsaturated acids of almost all straight-chain acids were found. It is remarkable that three types of eicosenic acids $(20: 1)$, with a quantity of $10 \cdot 7$ per cent and the continuation of it 
Table 3-FatTy acid composition of Homarus, Avicularia and Graphidostreptus

\begin{tabular}{|c|c|c|c|c|c|c|}
\hline \multirow[b]{2}{*}{$\begin{array}{l}\text { Shorthand } \\
\text { designation }\end{array}$} & \multirow{2}{*}{$\begin{array}{c}\text { Retention } \\
\text { time } \\
\text { relative } \\
\text { to } 18: 0\end{array}$} & \multicolumn{3}{|c|}{ Homarus } & \multirow[b]{2}{*}{$\begin{array}{c}\text { Avicularia } \\
(\%)\end{array}$} & \multirow[b]{2}{*}{$\begin{array}{c}\text { Graphido- } \\
\text { streptus } \\
(\%)\end{array}$} \\
\hline & & $\begin{array}{c}\text { Hepato- } \\
\text { pancreas } \\
(\%)\end{array}$ & $\begin{array}{c}\text { Muscles } \\
(\%)\end{array}$ & $\begin{array}{c}\text { Remaining } \\
\text { parts } \\
(\%)\end{array}$ & & \\
\hline Up to $14:$ br. & & $1 \cdot 7$ & $3 \cdot 2$ & $1 \cdot 7$ & $3 \cdot 5$ & $1 \cdot 0$ \\
\hline $14: 0$ & 0.260 & $1 \cdot 6$ & $1 \cdot 0$ & $2 \cdot 1$ & $2 \cdot 5$ & 0.7 \\
\hline $14: 1$ & 0.310 & - & - & - & $0 \cdot 3$ & - \\
\hline $15: 0$ neo & $0 \cdot 296$ & $0 \cdot 1$ & 0.9 & 0.1 & - & - \\
\hline $15: 0$ iso & $0 \cdot 310$ & 0.4 & 0.8 & 0.5 & $0 \cdot 2$ & 0.6 \\
\hline $15: 0$ anteiso & 0.330 & 0.2 & $0 \cdot 2$ & $0 \cdot 1$ & - & 0.3 \\
\hline $15: 0$ & 0.362 & $0 \cdot 7$ & $0 \cdot 3$ & $1 \cdot 3$ & 0.4 & 0.8 \\
\hline $15: 1$ & 0.423 & - & $0 \cdot 4$ & $0 \cdot 1$ & $0 \cdot 1$ & 0.3 \\
\hline $16: 0$ neo & 0.370 & $0 \cdot 2$ & $4 \cdot 0$ & $0 \cdot 2$ & - & - \\
\hline $16: 0$ iso & 0.436 & 0.4 & $14 \cdot 5$ & $0 \cdot 4$ & $2 \cdot 6$ & 0.8 \\
\hline $16: 0$ anteiso & 0.463 & 0.2 & $1 \cdot 0$ & - & - & - \\
\hline $16: 0$ & 0.517 & $16 \cdot 9$ & $16 \cdot 0$ & $25 \cdot 7$ & $31 \cdot 0$ & $25 \cdot 6$ \\
\hline $16: 1$ & 0.586 & $10 \cdot 3$ & $6 \cdot 0$ & $10 \cdot 5$ & $2 \cdot 2$ & $3 \cdot 7$ \\
\hline 17:0 neo & 0.531 & $1 \cdot 0$ & $2 \cdot 8$ & $3 \cdot 0$ & 0.8 & 0.6 \\
\hline $17: 0$ iso & 0.602 & $2 \cdot 2$ & $2 \cdot 3$ & $2 \cdot 2$ & 0.8 & 0.4 \\
\hline $17: 0$ anteiso & 0.651 & $1 \cdot 3$ & 0.3 & 0.5 & 0.4 & $0 \cdot 3$ \\
\hline $17: 0$ & 0.710 & $1 \cdot 3$ & 0.5 & 1.4 & $1 \cdot 2$ & 0.7 \\
\hline $17: 1$ & 0.804 & $1 \cdot 1$ & $1 \cdot 0$ & $2 \cdot 5$ & $0 \cdot 7$ & $2 \cdot 0$ \\
\hline $18: 0$ neo & 0.720 & 0.4 & $2 \cdot 5$ & Trace & - & $0 \cdot 3$ \\
\hline $18: 0$ iso & 0.851 & 0.8 & $5 \cdot 8$ & 0.9 & $0 \cdot 2$ & - \\
\hline $18: 0$ anteiso & 0.892 & $0 \cdot 3$ & $1 \cdot 0$ & Trace & - & - \\
\hline $18: 0$ & 1.00 & $2 \cdot 4$ & $7 \cdot 7$ & 6.8 & $12 \cdot 6$ & $5 \cdot 4$ \\
\hline $18: 1$ & $1 \cdot 12$ & $29 \cdot 9$ & $20 \cdot 7$ & $34 \cdot 2$ & $36 \cdot 0$ & $42 \cdot 5$ \\
\hline $18: 2$ & $1 \cdot 35$ & $0 \cdot 1$ & Trace & $0 \cdot 1$ & 0.2 & $2 \cdot 0$ \\
\hline $18: 3$ & 1.73 & Trace & - & - & - & - \\
\hline 19:0 neo & $1 \cdot 02$ & 0.8 & $2 \cdot 3$ & 0.5 & - & $2 \cdot 0$ \\
\hline $19: 0$ iso & $1 \cdot 16$ & 0.7 & Trace & - & 0.6 & - \\
\hline $19: 0$ anteiso & $1 \cdot 25$ & 0.6 & Trace & $0 \cdot 3$ & $0 \cdot 3$ & 0.4 \\
\hline $19: 0$ & $1 \cdot 37$ & $0 \cdot 3$ & 0.4 & $0 \cdot 3$ & 0.5 & 0.8 \\
\hline $19: 1$ & 1.53 & $2 \cdot 0$ & - & 0.9 & 0.2 & Trace \\
\hline 20:0 neo & $1 \cdot 37$ & - & 0.6 & - & - & 0.9 \\
\hline $20: 0$ iso & 1.59 & Trace & $1 \cdot 2$ & - & $0 \cdot 1$ & - \\
\hline $20: 0$ anteiso & 1.8 & - & - & - & - & 0.1 \\
\hline $20: 0$ & 1.89 & $0 \cdot 7$ & 0.5 & 0.6 & $1 \cdot 2$ & $1 \cdot 4$ \\
\hline $20: 1$ & $2 \cdot 11$ & $4 \cdot 8$ & $2 \cdot 1$ & $2 \cdot 1$ & 0.7 & $1 \cdot 0$ \\
\hline $20: 1$ & $2 \cdot 16$ & $4 \cdot 2$ & 0.4 & $>0.7$ & - & - \\
\hline $20: 1$ & $2 \cdot 26$ & $1 \cdot 7$ & 0.8 & $>0 \cdot 7$ & 0.8 & 一 \\
\hline $20: 2$ & $2 \cdot 52$ & 0.9 & $0 \cdot 1$ & 0.2 & - & $2 \cdot 0$ \\
\hline $20: 3$ & $2 \cdot 87$ & 0.7 & 0.2 & - & - & - \\
\hline $20: 4$ & $3 \cdot 17$ & Trace & - & - & - & - \\
\hline $21: 0$ neo & $2 \cdot 08$ & 一 & - & - & - & 0.6 \\
\hline $21: 0$ iso & $2 \cdot 19$ & - & - & - & - & 0.4 \\
\hline $21: 1$ neo? & $2 \cdot 41$ & - & - & - & - & $1 \cdot 2$ \\
\hline $21: 0$ & $2 \cdot 60$ & $0 \cdot 2$ & - & - & - & - \\
\hline
\end{tabular}


TABLE 3-continued

\begin{tabular}{lccccccc}
\hline & $\begin{array}{c}\text { Retention } \\
\text { time } \\
\text { Shorthand } \\
\text { relative } \\
\text { to } 18: 0\end{array}$ & $\begin{array}{c}\text { Hepato- } \\
\text { pancreas } \\
(\%)\end{array}$ & $\begin{array}{c}\text { Muscles } \\
(\%)\end{array}$ & $\begin{array}{c}\text { Remaining } \\
\text { parts } \\
(\%)\end{array}$ & $\begin{array}{c}\text { Avicularia } \\
(\%)\end{array}$ & $\begin{array}{c}\text { Graphido- } \\
\text { streptus } \\
(\%)\end{array}$ \\
\hline $21: 1$ & 2.99 & 0.4 & 0.2 & - & - & - \\
$22: 0$ & 3.66 & 0.5 & - & 0.1 & 0.2 & 0.8 \\
$22: 1$ & 3.97 & 1.2 & - & Trace & Trace & - \\
$22: 1$ & 4.11 & 1.3 & - & Trace & - & - \\
$22: 1$ & 4.39 & 1.9 & - & Trace & - & - \\
$23: 0$ neo? & 4.08 & - & - & - & - & 0.3 \\
$24: 0$ neo? & 5.75 & - & - & - & - & 0.5 \\
$24: 0$ & 6.93 & 1.5 & - & - & - & - \\
$25: 0$ neo? & 7.49 & 1.1 & - & - & - & - \\
\hline
\end{tabular}

in $22: 1$ acids with a quantity of 3.4 per cent were found in the hepatopancreas and to a lower extent in the muscles and remaining parts of Homarus.

Polyunsaturated acids were demonstrated for $\mathrm{C}_{18}$ and $\mathrm{C}_{20}$ acids only. On the strength of available markers and known retention times iso and anteiso fatty acids could be demonstrated. The neo-type was identified only on the ground of published retention times (Farquhar et al., 1959) and is identified tentatively only. However, it is of interest that we found a homologue series for this possible type of branching. The muscles of Homarus contain a considerable amount of branched acids ( 40.6 per cent) compared to the hepatopancreas ( 9.6 per cent) and the remaining parts (8.7 per cent). Also in Avicularia and Graphidostreptus branchedchain fatty acids were detected. The iso-type proved to be predominant in Avicularia and the neo-type, provided that the provisional identification is correct, in Graphidostreptus. Polyunsaturated fatty acids were scarce in both Avicularia and Graphidostreptus.

Table 4 presents the radioactivities of the fatty acids or of the conglomerates of some of these acids. The radioactivity is expressed in counts. $\mathrm{min}^{-1} \mathrm{mg}^{-1}$ methylated fatty acid or conglomerate of fatty acids, because there was no complete separation.

Table 5 gives the radioactivities of $1 \mathrm{mg}$ of the total mixtures.

The values under column II of Table 5 are in good agreement with those obtained by direct counting of $1 \mathrm{mg}$ methyl esters in PPO-POPOP-toluene* solution. Transesterifications (Pascaud, 1963) were checked. They were avoided by carrying out the analyses at about $182^{\circ} \mathrm{C}$.

The lobster hepatopancreas shows little activity in the fatty acids compared with the fatty acids of both the muscle and remaining parts. This might be expected from an isotope dilution effect. On the whole the radioactivity of the even- and odd-numbered straight-chain fatty acids is found to be proportional to

* PPO, 2,5-diphenyloxazole. POPOP, 1,4-bis[2-(5-phenyloxazolyl)]-benzene. 
TABLE 4-ThE Distribution OF ${ }^{14} \mathrm{C}$ IN THE DIFFERENT FATTY ACIDS AFTER ADMINISTRATION OF ACETATE-1 - ${ }^{14} \mathrm{C}$. RADIOACTIVITY IN COUNTS. MIN ${ }^{-1} \mathrm{MG}^{-1}$ METHYLATED FATTY ACID (SPECIFIC ACTIVITY)

\begin{tabular}{|c|c|c|c|c|}
\hline \multirow[b]{2}{*}{$\begin{array}{l}\text { Shorthand } \\
\text { designation }\end{array}$} & \multicolumn{2}{|c|}{ Homarus } & \multirow[b]{2}{*}{ Avicularia } & \multirow[b]{2}{*}{$\begin{array}{c}\text { Graphido- } \\
\text { streptus }\end{array}$} \\
\hline & $\begin{array}{l}\text { Hepato- } \\
\text { pancreas }\end{array}$ & $\begin{array}{l}\text { Remaining } \\
\text { parts }\end{array}$ & & \\
\hline Up to $14: \mathrm{br}$. & 129 & 3178 & 443 & 13,500 \\
\hline $14: 0$ & 103 & 4329 & 1092 & 18,557 \\
\hline $14: 1$ & - & - & 100 & - \\
\hline $15: 0$ neo & 150 & & - & - \\
\hline $15: 0$ iso. & 183 & 1228 & $2017^{*}$ & \\
\hline 15:0 anteiso & & & - & 10,800 \\
\hline $15: 0$ & 59 & 561 & - & 4050 \\
\hline $16: 0$ neo & & & - & - \\
\hline $16: 0$ iso & 27 & 642 & 408 & 6800 \\
\hline 16:0 anteiso & 28 & & 一 & - \\
\hline $16: 0$ & 252 & 3471 & 1573 & 18,858 \\
\hline $16: 1$ & 55 & 619 & 864 & 6621 \\
\hline $17: 0$ neo & 191 & & - & \\
\hline $17: 0$ iso & 191 & 650 & $92 b$ & 5446 \\
\hline $17: 0$ anteiso & 270 & & - & ) \\
\hline $17: 0$ & 165 & 1278 & 1166 & 13,471 \\
\hline $17: 1$ & 50 & & 14 & 3615 \\
\hline 18:0 neo & 275 & 848 & - & 18,400 \\
\hline $18: 0$ iso & 172 & & 4800 & - \\
\hline 18:0 anteiso & $1 / 2$ & 1370 & - & - \\
\hline $18: 0$ & 1142 & 5736 & 2173 & 49,394 \\
\hline $18: 1$ & 74 & 555 & 141 & 4353 \\
\hline $18: 2$ & - & 一 & - & - \\
\hline $18: 3$ & 一 & 一 & - & - \\
\hline 19:0 neo & & & - & \\
\hline $19: 0$ iso & 322 & 1100 & 1750 & $10,555 \dagger$ \\
\hline $19: 0$ anteiso & 232 & & 1666 & \\
\hline 19:0 & $256 \ddagger$ & $2833 \S$ & 1800 & 52,100 \\
\hline $19: 1$ & 670 & 2711 & 2050 & $?$ \\
\hline $20: 0$ neo & $?$ & $?$ & - & \\
\hline $20: 0$ iso & ? & 一 & 13,300 & 6333 \\
\hline $20: 0$ anteiso & - & - & - & \\
\hline $20: 0$ & 1263 & 7633 & 3150 & 27,800 \\
\hline $20: 1$ & & & 1071 & $12,875 \|$ \\
\hline $20: 1$ & 135 & 4429 & - & - \\
\hline $20: 1$ & & & 2475 & - \\
\hline $20: 2$ & 66 & 2700 & - & $?$ \\
\hline $20: 3$ & 23 & - & - & - \\
\hline $20: 4$ & - & - & - & - \\
\hline $21: 0$ neo & 一 & - & - & $?$ \\
\hline $21: 0$ iso & 一 & - & - & $105,466 \pi$ \\
\hline $21: 0$ & 160 & - & 一 & 171,000 \\
\hline $21: 1$ neo? & - & - & - & ? \\
\hline
\end{tabular}


TABLE 4-continued

\begin{tabular}{|c|c|c|c|c|}
\hline \multirow[b]{2}{*}{$\begin{array}{l}\text { Shorthand } \\
\text { designation }\end{array}$} & \multicolumn{2}{|c|}{ Homarus } & \multirow[b]{2}{*}{ Avicularia } & \multirow[b]{2}{*}{$\begin{array}{c}\text { Graphido- } \\
\text { streptus }\end{array}$} \\
\hline & $\begin{array}{l}\text { Hepato- } \\
\text { pancreas }\end{array}$ & $\begin{array}{l}\text { Remaining } \\
\text { parts }\end{array}$ & & \\
\hline $21: 1$ & $?$ & - & - & - \\
\hline $22: 0$ & 2360 & 9285 & 21,550 & 118,925 \\
\hline $22: 1$ & & & $?$ & - \\
\hline $22: 1$ & 402 & $?$ & - & - \\
\hline $22: 1$ & & & - & - \\
\hline $23: 0$ neo? & - & - & - & 108.050 \\
\hline 24:0 neo? & - & - & - & $\delta, U \supset U$ \\
\hline $24: 0$ & 215 & 一 & - & - \\
\hline $25: 0$ neo? & 309 & - & - & - \\
\hline
\end{tabular}

* Including 15:0. † Except 19:0 iso.

$\ddagger$ Including 20:0 neo. \$Including 20:0 neo.

II Except 20:0 iso. II Including 20:2, 21:1.

Table 5-The Radioactivity of $1 \mathrm{mg}$ Methylated FatTy ACID MixtURE

\begin{tabular}{lrr}
\hline & \multicolumn{1}{c}{ I } & \multicolumn{1}{c}{ II } \\
\hline Homarus & & \\
Hepatopancreas & $182 \cdot 5$ & $186 \cdot 1$ \\
Muscle & $395 \cdot 3$ & \multicolumn{2}{c}{} \\
Remaining parts & $2048 \cdot 0$ & $2030 \cdot 4$ \\
Avicularia & $1184 \cdot 0$ & $1102 \cdot 4$ \\
Graphidostreptus & $18,201 \cdot 1$ & $18,163.9$ \\
\hline
\end{tabular}

I. The radioactivity of $1 \mathrm{mg}$ methylated fatty acids, determined by liquid scintillation counting in PPO-POPOP, according to the method of Hayes et al. (1956). The results expressed in counts/min were calculated at 100 per cent counting efficiency.

II. The radioactivity in counts/min after summation of the radioactivities (determined on anthracene cartridges by scintillation counting) of the separate components from $1 \mathrm{mg}$ mixture of methyl esters.

the increase of the number of carbon atoms. This phenomenon is also found in Avicularia and Graphidostreptus. The biosynthesis of these fatty acids must take place almost completely by way of the elongation system, by either the mitochondrial (Wakil, 1961, 1962) or microsomal system (Nugteren, 1965). Possibly the mono-unsaturated acids have been synthesized from the corresponding saturated acids, because the labelling with radiocarbon of the former is lower than the latter in all cases except that of 19:1, which exceeded that of 19:0. However, it is possible that during the experiments most of the produced 19:0 was dehydrogenated directly to $19: 1$. 
The polyunsaturated acids, linoleic (18:2), linolenic (18:3) and arachidonic (20:4), nowhere show radioactivity. In Astacus astacus (Zandee, 1966b) linoleic acid was stated to be essential; it is possible that the same is true for Homarus, although in this animal very much less of this acid is present. The branched-chain fatty acids are labelled distinctly, and the labelling is relatively high in all the animals investigated.

\section{DISCUSSION}

The experiments described in this paper show that the representatives of the Arthropoda, namely Homarus gammarus (L.), Avicularia avicularia (L.) and Graphidostreptus tumuliporus (Karsch), do not incorporate acetate into cholesterol or into its precursor, squalene. These findings agree with the results found for the crustaceans Astacus astacus (L.) (Zandee, 1962, 1964, 1966a), Cancer pagurus (L.) (Van den Oord, 1964), Lepas anatifera (L.) and Eupagurus bernhardus (L.) (Zandee, unpublished data). The results found for insects, for crustaceans and for Avicularia and Graphidostreptus support the assumption that all the groups of Arthropoda have a dietary requirement for cholesterol or other sterols.

The predominant sterol, cholesterol, present in the animals investigated is of dietary origin. The carnivorous animals will find cholesterol in their food but a herbivorous animal like the diplopode Graphidostreptus will not. The latter depends on the phytosterols of its food. Since cholesterol is the most important sterol in Graphidostreptus it must be supposed that the animal can modify phytosterols into cholesterol. The amount of cholesterol in the animals of the phylum Arthropoda investigated is very small compared with that of the vertebrates. It is a known fact that most vertebrates produce large quantities of bile acids from cholesterol. The bile salts are highly important for lowering the surface tension and increasing the emulsification, the digestion and absorption of fat and fat-soluble vitamins.

In the gastric juice of Crustacea and of other invertebrates surface active compounds were shown to be present (Vonk, 1935, 1960, 1962). It was demonstrated by Van den Oord et al. (1964) that no bile acids or bile alcohols were present in the gastric juice of the crab Cancer pagurus. The isolated emulsifiers in the crab appeared to be fatty acylsarcosyltaurines (Van de Oord et al., 1965). Recently the biosynthesis of the emulsifiers from the gastric juice of the crab Cancer pagurus has been described by Van den Oord (1966). It was demonstrated that no sterols are involved in emulsifying properties of the gastric juice. It is possible that no bile acids will be found in invertebrates and that inability to synthesize cholesterol is correlated with the inability to degrade cholesterol to bile acids.

The fatty-acid composition of Homarus gammarus is in agreement with that of Astacus astacus (Zandee, 1966b). The essential fatty acids (18:2 and 18:3), so called because no labelling was found in these acids, are present in Astacus in considerable amounts. The much lower percentages of the essential fatty acids and other polyunsaturated fatty acids in Homarus may be due to the season and to the temperature of the North Sea. 
In Astacus of Polish origin 0.43 per cent, and in Astacus of Yugoslav origin 0.13 per cent of fatty acids (of the total fresh weight) were found (Zandee, 1966a). For linoleic acid we have demonstrated an average percentage of 10.1 per cent in the fatty-acid mixtures of Polish origin and of 3.7 per cent in those of Yugoslav origin (Zandee, 1964).

The fatty-acid mixtures of Graphidostreptus and Avicularia were liquid at $25-30^{\circ} \mathrm{C}$ just as the mixtures of Astacus and Homarus were at $15-20^{\circ} \mathrm{C}$. Probably these differences are related to the temperature by which the animals live under normal conditions. Studies on crustacean fatty-acid composition have demonstrated a characteristic annual cycle (Herodek \& Farkas, 1959; Farkas \& Herodek, 1959). The animals obviously are able to adapt themselves to the environmental temperature of the milieu by changing the amount of the polyunsaturated acids. The high content of polyunsaturated acids in marine fish oil and in fresh-water fish, especially in winter (Kelly et al., 1958; Farkas \& Herodek, 1964), will give the animals mobility and flexibility in swimming.

Although fresh-water and marine animals probably show adaptation to the environmental temperature by changing the fatty-acid composition, this phenomenon was not found for Graphidostreptus and Avicularia. These animals show a great activity at $25-30^{\circ} \mathrm{C}$. Gradual lowering of the temperature to $15^{\circ} \mathrm{C}$ is attended by a decrease in metabolic activity. Prolonged lowering to about $15^{\circ} \mathrm{C}$ appeared fatal.

The hydrocarbons and other wax-like substances of Graphidostreptus and Avicularia are more highly labelled than the fatty acids. Presumably these compounds were synthesized from the fatty acids with a great number of carbon atoms because these acids are always very radioactive compared to those of shorter chain length.

The greatest number of branched-chain acids with an even and odd number of carbon atoms was shown in Graphidostreptus. It is possible that these acids were used to synthesize the hydrocarbons and wax-like substances. The epicuticle of the exoskeleton contains large amounts of wax, which protect the animal against desiccation (Edney, 1957).

In general the metabolism of the fatty acids in Homarus, Avicularia and Graphidostreptus follows the same pathways as described for Astacus (Zandee, 1966b). To gain more insight into the biosynthesis of the several fatty acids more detailed studies are necessary.

Acknowledgements-The author is much indebted to Prof. H. J. Vonk for his helpful advice. The technical assistance of Miss E. C. J. Kruitwagen is gratefully acknowledged.

This work was supported in part by a grant of the Netherlands Organization for the Advancement of Pure Research (Z.W.O.).

\section{REFERENCES}

BERGMANN W. (1962) Sterols: Their structure and distribution. In Comparative Biochemistry (Edited by Florkin M. \& Mason S.) Vol. 3, pp. 103-162. Academic Press, New York. Bloch K., Langdon R. G., Clark A. J. \& Fraenkel G. (1956) Impaired steroid biogenesis in insect larvae. Biochim. biophys. Acta 21, 176. 
Calvin M., Heidelberger C., Reid J. C., Tolbert B. M. \& Yarkwich P. E. (1949) Isotopic Carbon. p. 29. Wiley, New York.

Clark A. J. \& Bloch K. (1959) The absence of sterol synthesis in insects. F. biol. Chem. 234, 2578-2582.

Clayton R. B. (1964) The utilization of sterols by insects. F. Lipid Res. 5, 3-19.

EDNEY E. B. (1957) The water relations of terrestrial Arthropods. Cambridge Monographs in Experimental Biology. Vol. 5. Cambridge University Press, London, New York.

FAGRRLUND U. H. M. \& IDleR D. R. (1960) Marine sterols-VI. Sterol biosynthesis in molluscs and echinoderms. Can. F. Biochem. Physiol. 38, 997-1002.

Farkas T. \& Herodek S. (1959) Paper chromatographic studies on the fatty acid composition of some fresh-water crustaceans. Acta biol. hung. 10, 85-90.

FARKAS T. \& HERODEK S. (1964) The effect of environmental temperature on the fatty acid composition of crustacean plankton. F. Lipid Res. 5, 369-373.

Farquhar J. W., Insull W., Rosen P., Stoffel W. \& Ahrens E. H. (1959) The analysis of fatty acid mixtures by gas-liquid chromatography. Construction and operation of an ionization chamber instrument. Nutr. Rev. 17, 1-30 (Suppl.).

Gilmour D. (1961) Biochemistry of Insects. pp. 32-36. Academic Press, New York.

Gosselin L. (1965) L'utilisation de l'acide mévalonique-2- ${ }^{14} \mathrm{C}$, in vivo, dans l'hépatopancréas de Astacus fluviatilis. Archs int. Physiol. Biochim. 73, 543-544.

Hayes F. N., Rogers B. S. \& Langham W. H. (1956) Counting suspensions in liquid scintillators. Nucleonics 14, 48-51.

HERODEK S. \& FARKAS T. (1959) Seasonal changes in the fatty acid composition of Astacus leptodactylus. Acta biol. hung. 10, 53-59.

Kaplanis J. N., DutKy R. C. \& RobBins W. E. (1961) The incorporation of $2-{ }^{14} \mathrm{C}-$ mevalonate into housefly lipids. Ann. ent. Soc. Am. 54, 114-116.

Kaplanis J. N., Robeins W. E., Vroman H. E. \& Bryce B. M. (1963) The absence of cholesterol biosynthesis in a primitive insect--the firebrat, Thermobia domestica (Packard). Steroids 2, 547-550.

Karmen A., Giufrrida L. \& Bowman R. L. (1962) Radioassay by gas-liquid chromatography of lipids labelled with carbon-14. F. Lipid Res. 3, 44-52.

Kelly P. B., Reiser R. \& Hood D. W. (1958) The effect of diet on the fatty acid composition of several species of fresh-water fish. F. Am. Oil Chem. Soc. 35, 503-505.

KoDiceK E. \& Levinson Z. H. (1960) Metabolism of $\beta$-sitosterol and other lipids in the presence of acetate-2-14 C by blowfly larvae. Nature, Lond. 188, 1023-1025.

Loud A. V. \& Bucher N. L. R. (1958) The turnover of squalene in relation to the biosynthesis of cholesterol. F. biol. Chem. 233, 37-41.

NUGteren D. H. (1965) The enzymic chain elongation of fatty acids by rat-liver microsomes. Biochim. biophys. Acta 106, 280-290.

Pascaud M. (1963) Contaminations en chromatographie gas-liquide d'esters d'acides gras radioactifs sur phase stationnaire polyester. F. Chromat. 10, 125-130.

RENaud L. (1949) Le cycle des réserves organiques chez les crustacés décapodes. Annls Inst. océanogr., Monaco 24, 259-357.

Robbins W. E., Kaplanis J. N., Louloudes S. J. \& Monroe R. E. (1960) Utilization of $1{ }^{14} \mathrm{C}$-acetate in lipid synthesis by adult house flies. Ann. ent. Soc. Am. 53, 128-129.

SchienK H. \& Gellerman J. L. (1960) Esterification of fatty acids with diazomethane on a small scale. Analyt. Chem. 32, 1412-1414.

SEDEe PH. D. J. W. (1961) Intermediary metabolism in aseptically reared blowfly larvae, Calliphora erythrocephala (Meig.)-I. Biosynthesis of squalene and cholesterol. Archs. int. Physiol. Biochim. 69, 284-294.

VAN DEN OORD A. (1964) The absence of cholesterol synthesis in the crab Cancer pagurus L. Comp. Biochem. Physiol. 13, 461-467.

VAN DEN OORD A. (1966) The biosynthesis of the emulsifiers of the crab Cancer pagurus $\mathrm{L}$. Comp. Biochem. Physiol. 17, 715-718. 
VAN den Oord A., Danielsson H. \& Ryhage R. (1964) Absence of bile salts in the gastric juice of a crab. Nature, Lond. 203, 301.

Van den OoRd A., Danielsson H. \& Ryhage R. (1965) On the structure of the emulsifiers in gastric juice from the crab, Cancer pagurus L. F. biol. Chem. 240, 2242-2247.

VoNK H. J. (1935) Die Eigenschaften des Verdauungssaftes von Potamobius (Astacus) leptodactylus und anderen Invertebraten in Bezug auf die Fettresorption. $Z$. vergl. Physiol. 21, 717-738.

Vonk H. J. (1960) Digestion and metabolism. In The Physiology of Crustacea (Edited by Waterman T. H.) Vol. 1, pp. 291-316. Academic Press, New York.

VoNk H. J. (1962) Emulgators in the digestive fluids of invertebrates. Archs int. Physiol. Biochim. 70, 67-85.

WAKIL S. J. (1961) Mechanism of fatty acid synthesis. F. Lipid Res. 2, 1-24.

WaKIL S. J. (1962) Lipid metabolism. A. Rev. Biochem. 31, 369-406.

Wootton J. A. M. \& Wright L. D. (1962) A comparative study of sterol biosynthesis in Annelida. Comp. Biochem. Physiol. 5, 253-264.

ZANDEE D. I. (1962) Lipid metabolism in Astacus astacus (L.). Nature, Lond. 195, 814-815.

ZANDEE D. I. (1964) Het metabolisme van Astacus astacus (L.) en enige andere Arthropoda (Metabolism in Astacus astacus (L.) and some other Arthropoda). Thesis, Utrecht University.

ZandeE D. I. (1966a) Metabolism in the crayfish Astacus astacus (L.)--III. Absence of cholesterol synthesis. Archs int. Physiol. Biochim. 74, 435-441.

ZANDEE D. I. (1966b) Metabolism in the crayfish Astacus astacus (L.)-IV. The fatty acid composition and the biosynthesis of the fatty acids. Archs int. Physiol. Biochim. 74, 614-626. 